\title{
COMPARISON ANALYSIS AND CONTROL PROCEDURES OF LABOR WORKFORCE EFFICIENCY OF MILK PROCESSORS IN VISEGRAD GROUP AND RUSSIA
}

\author{
Stanislava Kontsevaya ${ }^{1}$, Jindřich Špička², Irina Kharcheva ${ }^{3}$, \\ Irina Makunina ${ }^{3}$, Raisa Kostina ${ }^{3}$
}

\begin{abstract}
${ }^{1}$ Department of Economics, Faculty of Economics and Management, Czech University of Life Sciences, Prague, Kamycka 129, 16521 Praha 6, Czech Republic

${ }^{2}$ Department of Strategy, Faculty of Business Administration, University of Economics, Prague, nám. W. Churchilla 4, 13067 Praha 3, Czech Republic

${ }^{3}$ Faculty of Economics and Finance, Russian Timiryazev State Agrarian University, Timiryazevskaya st. 49, 127550, Moscow, Russia
\end{abstract}

\begin{abstract}
KONTSEVAYA STANISLAVA, ŠPIČKA JINDŘICH, KHARCHEVA IRINA, MAKUNINA IRINA, KOSTINA RAISA. Comparison Analysis and Control Procedures of Labor Workforce Efficiency of Milk Processors in Visegrad Group and Russia. Acta Universitatis Agriculturae et Silviculturae Mendelianae Brunensis, 66(1): 263-272.
\end{abstract}

The aim of an article is to make comparison analysis of labor productivity efficiency in milk processing industry. An investigated object is a data base of accounting reports of 5 countries in the Czech Republic, the Slovak Republic, Poland, Hungary and Russia over the period of 2011-2013. The number of selected companies is 619. a hypothesis of the research: there is significant correlation between salary and labor productivity in milk processing industry. Difference between Visegrad group and Russia is tested with Kolmogorov-Smirnov test at significance level of 0.05. Representativity of data is checked by Chi-Square test. Relationship between workforce productivity and salary is made by Spearman's rank correlation. In Visegrad group, relationship between workforce productivity and salary are presented by volume of coefficient 0.7189. Russian companies have coefficient 0.1208.

Generally speaking, there is sufficiently great dependence between salary and labor productivity in Visegrad group and there is no dependence in Russia. a worker can see no dependence between high salary and high productivity in Russia that is The possible reason of low correlation between salary and labor productivity. This fact suggests methodology to control efficiency of labor workforce. The methodology is based on coefficients, given to each employee, in order to estimate his productivity and compare it with other employees or compare companies between each other.

Keywords: Dairy industry, milk processing, financial analysis, controlling, statistical analysis

\section{INTRODUCTION}

Milk production concerns vital branches of food industry and its normal functioning provides food safety of the country. One of the major factors of production is human resources. Effectiveness of their work produces positive or negative economic results (Borská et al., 2015).

To keep a competitive position each company must renovate its equipment. It should also improve, expand and change a volume of products. Therefore, it is important to have high qualified workers. According to investigation in Russia (Rastamkhanova, 2009), there is 60 percent of processing companies, suffering from shortage in qualified workers 
(production engineers) and managers. Two job offers suit one high qualified production engineer. Another side of this situation is inconformity of future workers to company's requirements and level of qualification of workers, who pretend to get a job. Companies take low qualified workers with small salary. It results in low labor productivity. According to Russian statistical Federal state statistics service of the Russian Federation, a gap of salaries can be more than 2.5 times depending on region. An amount and productivity of work is the same. Managers in both public and private companies are searching for new ways to manage their employees more effectively (Urbancová et al., 2015). Actual question is that, how does salary growth lead to labor productivity growth? How does complex labor productivity growth and salary growth lead to profit?

According to Adam Smith's classic economic theory, there is direct dependence between salary and labor productivity (Blaug, 1994). In case of perfect competition, a company maximizes profit, when salary level is settled on marginal utility of labor productivity. Real life is far from being ideal, that is why direct relation between labor productivity and salary is invisible. Moreover, long-term outlook makes correlation between factors complicated.

Economic schools have different points of view on variety of correlations between salary and labor productivity. What factor might be dependent or independent?

Firstly, it is considered that salary and labor productivity have strong positive correlation. Salary is dependent variable. Empirical investigation demonstrates availability of close and long-time correlation at country level. (Meager et al., 2011). Comparative investigation shows big difference in relationships between parameters. (Klein, 2012). At macro level there is long-term cointegrated connection between labor productivity-salary-unemployment (Pascalau, 2007).

Secondly, a conception of "Efficiency wages" should be described. This conception predicts opposite direction. Salary is independent variable. It explains stimulating effect of high salary on labor workforce. (Shapiro, Stiglitz, 1984). Several papers presented practical results and confirmation of the fact, that growing salary positively influences workforce (Millea, 2002; Dohmen et al., 2014).

In this paper it is taken, that there is relationship between salary and labor productivity.

It is not enough to increase salary for labor productivity growth. Procedures must be developed in order to control efficiency of labor productivity. Otherwise, company bears losses, because salary costs have no effect (Alborov et al., 2014).

Dairy industry condition in Visegrad group and Russia is presented in Tab. XI and Figs. 1-3 (Source: Faostat database, The author's calculation). Russia is quite dependent from imported milk but currently it does its best to become more independent. However, Russia imported more than
2,257 thou. tons of milk in 2011 and exported only 235 thou. tons. In Visegrad group Poland produced the biggest quantity of milk, more than $12 \mathrm{mln}$. tons and more than $1 / 4$ of product was exported to the other countries in 2011. Comparing growth of prices (Fig. 1), Russia demonstrated the most significant and stable growth among investigated countries for 20 years. This growth is more than 250 times. It should be noted that the period 2004-2006 is taken as 100 percent. In Russia consumption per head of population over that period has grown too (Fig. 2) and now it is equal to average consumption in Visegrad group. Milk yield per cow, measured in $\mathrm{kg}$ per year, has been growing during investigated period in all countries (Fig. 3). It is caused by technical progress and improvement of milk cattle breeds. Nevertheless, these countries have difficulties in competition with the USA, where milk yield per cow is 9 thou. $\mathrm{kg}$ per year. Productivity of cow is not the main factor of overall volume. Poland is the leader among other countries in spite of less productivity.

The aim of the article is to make comparison analysis of labor productivity efficiency in milk processing industry in Visegrad group and the Russia Federation in the period 2011-2013 year.

The tasks of the article are set in order to achieve the aim:

- Estimation of current condition of dairy industry in Visegrad group and Russia.

- Scientifically based statistical selection and relevant dataset.

- Making the hypothesis, that there is correlation between labor productivity and salary in milk processing industry.

- Comparison analysis of obtained results between Russia and Visegrad group.

- Suggesting procedures to control efficiency of salary and labor productivity.

The hypothesis of the research. The null hypothesis: there is no any correlation between salary and labor productivity. Alternative hypothesis: there is significant correlation between salary and labor productivity in milk processing industry.

\section{MATERIALS AND METHODS}

Comparison analysis of labor workforce is based on official data from Eurostat and individual accounting data belonging to companies from Amadeus database and Federal State Statistics Service of the Russian Federation (Rosstat). Panel data is selected from NACE Rev. 2 (Code C10.5). Analyzed data belongs to the period 2011-2013. Taking more than 3 years data essentially decreases number of inquired companies.

Total dataset contains 478 company from Russia and 141 from Visegrad group (the Czech Republic, the Slovak Republic, Poland, Hungary). The basic dataset describes in details each country by 
5 characteristic. The size of the company is presented by operating revenue (turnover) and assets. Workforce of company is presented by number of employees, revenue per person and salary per person. The Tab. I presents condition in Russia and the Tab. II-condition in Visegrad group. The data in these two tables is exposed to cleaning process. It contains extreme min and max.

Special statistical software Stata 13 is used in order to make analysis. The dataset for analysis is presented by average value of each rate for 3 years. It means that each company of 619 companies has 5 indicators for statistical analysis.

Comparing rates of Russia and Visegrag group, it should be mentioned, that size of company is more heterogeneous in Russia. Russian standard deviation of operation revenue exceeds Mean 2.79 times. In Visegrad group this rate is only 2.41 times. Situation of assets is the same i.e. Russia has 5.39 times excess, Visegrad group - 2.26 times excess. It means that size of company in Visegrad group is less different then in Russia.

Analysis of Mean in these 2 groups identifies almost 2 times difference of revenue per person and salary per person at relatively equal number of people (150 and 200) and assets (12 mln and $11 \mathrm{mln}$ ).

In Russia both salary and labor productivity is low but in the EU situation is opposite. According to Tab. I and Tab. II it should be concluded that there is close relationship between salary and labor productivity growth. Small salary leads to small productivity in Russia and big salary leads to big productivity in Visegrad group.

According to Amadeus database classification, a company is considered major, if at least one of the following conditions is met: operating revenue $\geq 10 \mathrm{mln}$ EUR, total assets $\geq 20 \mathrm{mln}$ EUR, number of employees $\geq 150$ people. Operating revenue and number of employees satisfies

I: Key features of The basic dataset in Russia

\begin{tabular}{lcccccc}
\hline \multicolumn{1}{c}{ Russia } & Symbol & Obs & Mean & Std. Dev. & Min & Max \\
\hline Operating revenue & Thou. EUR & 478 & $19,727.35$ & $94,565.08$ & 15.48 & $1,664.556$ \\
Assets & Thou. EUR & 478 & $11,489.20$ & $61,962.70$ & 1.43 & $96,5951.5$ \\
Employees & number & 478 & 206.61 & 588.47 & 5 & 10,337 \\
Revenue per person & Thou. EUR & 478 & 77.76 & 132.25 & 1 & 1,103 \\
Salary per person & Thou. EUR & 478 & 5.00 & 1.89 & 2 & 12 \\
\hline
\end{tabular}

Source: Amadeus database, Rosstat, The author's calculation

II: Key features of The basic dataset in V4

\begin{tabular}{lcccccc}
\hline \multicolumn{1}{c}{ V4 } & Symbol & Obs & Mean & Std. Dev. & Min & Max \\
\hline Operating revenue & Thou. EUR & 141 & $28,801.86$ & $69,276.89$ & 16.02 & $695,228.7$ \\
Assets & Thou. EUR & 141 & $12,639.01$ & $28,561.66$ & 4.42 & $284,249.3$ \\
Employees & number & 141 & 150.38 & 263.34 & 1 & 1,967 \\
Revenue per person & Thou. EUR & 141 & 143.59 & 170.60 & 3 & 1,211 \\
Salary per person & Thou. EUR & 141 & 10 & 4.85 & 2 & 32 \\
\hline
\end{tabular}

Source: Amadeus database, Rosstat, The author's calculation

III: Sample size in turnover in 2013, thou. EUR

\begin{tabular}{lcccccc}
\hline Operating revenue & $\begin{array}{c}\text { Czech } \\
\text { Republic }\end{array}$ & Poland & $\begin{array}{c}\text { Slovak } \\
\text { Republic }\end{array}$ & Hungary & V4 Total & Russia \\
\hline Sample & $1,348.0$ & $1,264.4$ & 545.76 & 902.82 & $4,060.98$ & $9,429.7$ \\
Population & $1,719.0$ & $7,375.7$ & 653.6 & 948.1 & $10,696.40$ & $10,751.4$ \\
Share,\% & 78.42 & 17.14 & 83.5 & 95.22 & 37.97 & 87.71 \\
\hline
\end{tabular}

Source: The author's calculation, Eurostat

IV: Sample size of population in 2013

\begin{tabular}{lcccccc}
\hline $\begin{array}{c}\text { Number of } \\
\text { companies }\end{array}$ & $\begin{array}{c}\text { Czech } \\
\text { Republic }\end{array}$ & Poland & $\begin{array}{c}\text { Slovak } \\
\text { Republic }\end{array}$ & Hungary & V4 Total & Russia \\
\hline Sample & 44 & 16 & 32 & 49 & 141 & 478 \\
Population & 178 & 525 & 189 & 106 & 998 & 1,192 \\
Share, \% & 24.72 & 3.05 & 16.93 & 46.23 & 14 & 40.10 \\
\hline
\end{tabular}

Source: The author's calculation, Eurostat 
requirements for major company in both Russia and V4. Thus, only major companies are investigated.

To check representativeness of the dataset, it is required to bring into comparison a sample with total population in each group.

Evaluation of data representativeness is shown in Tab. III and Tab. IV. These tables aggregate comparison of dataset samples and total population in each region.

In case of turnover comparison analysis, population samples of each country are 80 percent or more, except for Poland. There is less information about salaries in this country. Therefore, Visegrad group presented only 37.97 percent of population. Concerning Poland, there is no opportunity to make any conclusion about work force and salary. Because, Poland companies did not provide a lot of information about salary to Amadeus dataset.

Comparison analysis of company size states that less than 40 percent of population is presented. This fact confirms abovementioned conclusion that only major companies are investigated. So this article is devoted to investigation of market leaders in milk processing market. In addition statistic «Goodness of Fit Test» or Chi-Square test should be done to confirm representativeness of data samples.

The whole dataset is subjected to cleaning process. An outliner of each indicator is deleted. For this reason, The number of objects is different for the same country and indicators are various.

To check representativeness of data samples, "Goodness of Fit Test» should be used. Method "Goodness of Fit Test» is used to prove that distribution of selected sample is very close to distribution of population (Paul et al., 2001).

The null hypothesis states that observed number of cases in each country is exactly equal to expected number of cases. The alternative hypothesis states that both observed and expected numbers of cases are sufficiently distinguished to reject the null hypothesis. In other words, if the null hypothesis cannot be rejected, The sample submits to the same principle as whole population.

$\mathrm{O}_{\mathrm{i}}$ is observed number of cases in category $\mathrm{i}$, and $\mathrm{E}_{\mathrm{i}}$ is expected number of cases in each category, $\mathrm{i}=1,2,3, \ldots, \mathrm{k}$, and there are $\mathrm{k}-1$ degrees of freedom:

$\mathrm{H}_{0}: \mathrm{O}_{\mathrm{i}}=\mathrm{E}_{\mathrm{i}}$

$\mathrm{H}_{\mathrm{A}}: \mathrm{O}_{\mathrm{i}} \neq \mathrm{E}_{\mathrm{i}}$

Test statistic is:

$X^{2}=\sum_{i} \frac{\left(\mathrm{O}_{\mathrm{i}}-\mathrm{E}_{\mathrm{i}}\right)^{2}}{\mathrm{E}_{\mathrm{i}}}$

Chi square distribution with $\mathrm{k}-1$ degrees of freedom is used to determine critical $\mathrm{X}^{2}$ value for the test.
To provide significance of analysis results, different statistical tests are used. These tests are Shapiro-Wilk test (Royston, 1992), variance-comparison test, Kolmogorov-Smirnov test (Conover, 1999).

If the results of Shapiro-Wilk normality test show, that the dataset hasn't normal distribution and the two group variance-comparison test shows availability of significant differences between two groups, Kolmogorov-Smirnov test should be used for investigation of any differences in distribution of variable for two groups. It is alternative test for non-normal distributional data. If P-value is less than chosen alpha level $(a=0.05)$, two samples have significant differences.

P-value for this statistic may be obtained by evaluating asymptotic limiting distribution. Sample size for the first sample is $\mathrm{m}$, and sample size for the second sample is $n$.

$$
\begin{aligned}
& \lim _{n \rightarrow \infty} \operatorname{Pr}\left\{\sqrt{m n /(m+n)} \quad D_{m, n} \leq z \quad=\right. \\
& =1-2 \sum_{i=1}^{\infty}(-1)^{i-1} \quad \exp \left(-2 i^{2} z^{2}\right)
\end{aligned}
$$

Corrected p-value is obtained by modifying the asymptotic $\mathrm{p}$-value by using a numerical approximation technique.

$$
\begin{aligned}
& \mathrm{Z}=\Phi^{-1}\left(\mathrm{P}_{\alpha}\right)+1.04 / \min (\mathrm{m}, \mathrm{n})+2.09 / \max (\mathrm{m}, \mathrm{n})- \\
& -1.35 / \sqrt{\mathrm{mn} /(\mathrm{m}+\mathrm{n})} \mathrm{p}-\text { value }=\Phi(\mathrm{Z})
\end{aligned}
$$

where $\Phi(-)$ is cumulative normal distribution.

To identify dependence between salary and operation revenue, it is suggested to use method of correlation. This method indicates level of dependence between two factors. Fig. 1 proves straight relation, where 0 indicates that factors are absolutely independent.

In the database there is both discrete and continuous data. Discrete data is salary and continuous data is labor productivity. It is specific data from Russian government statistic. Utilization of pairwise correlation is not needed in this case. Therefore, we use Spearman's rank correlation (Conover, 1999) coefficients for all pairs of variables.

The way of controlling, measuring and comparing labor productivity depends on methodology. High labor productivity is not always measured by money. It is suggested to take methodology (Alborov et.al., 2014) for estimation of labor productivity in milk processing companies. According to this method coefficient $\mathrm{K}$ defines value of labor productivity of one worker with regard to influence of the following factors: work complexity; labor-output ratio of work; intensity of labor; degree of hazard and danger at work; norms execution (production) in Tab. V. 
$\mathrm{K}=\mathrm{t}_{1} \times \mathrm{K}_{\mathrm{wc}} \times \mathrm{K}_{\text {lor }} \times \mathrm{K}_{\mathrm{int}} \times \mathrm{K}_{\mathrm{hd}} \times \mathrm{K}_{\mathrm{nex}}$

$\mathrm{t}_{1}$ - duration of working day (8 hours), to 100 percent, and translated into the coefficient of 1 ;

$\mathrm{K}_{\mathrm{wc}}-$ coefficient of work complexity;

$\mathrm{K}_{\text {lor }}$ - coefficient of labor-output ratio;

$\mathrm{K}_{\text {int }}-$ coefficient of work intensity;

$\mathrm{K}_{\mathrm{hd}}-$ coefficient of hazard and danger at work;

$\mathrm{K}_{\text {nex }}$ - coefficient of norms execution (production).

These factors characterize extent of influence of factors in evaluation of a worker. The value of these coefficients is based on practical experience. The more intensity or dangerous work, The more coefficients, The more salary should be.

Factor of complexity $\left(\mathrm{K}_{\mathrm{wc}}\right)$ is characterized by complexity of means of production process. It may be of five degrees, corresponding to number of points from 0.01 to 0.05 .

Factor of labor-output ratio $\left(\mathrm{K}_{\text {lor }}\right)$ is determined by weight of work, cost of physical conditions of an environment where an employee is required to do work (emphasis strength, vision, position of body, arms and legs while running, etc.). It may also have five degrees, corresponding to number of points from 0.01 to 0.05 .

Factor of work intensity $\left(K_{\text {int }}\right)$ is characterized by responsibility of the employee to comply with different technological requirements for intensification of production processes, observance of values of instruments of labor, raw materials, finished products, feed, seed, and others. It may have four levels, corresponding to number of points from 0.01 to 004.

Factor of hazard and danger of work $\left(K_{\mathrm{hd}}\right)$ is determined by special working conditions, adversely affecting employee's health (temperature, pollution, noise, vibration, toxic substances, etc.). It may also have four levels, corresponding to number of points from 0.01 to 0.04 .
Labor productivity ( $\mathrm{LP}_{\text {product }}$ ) may be estimated by means of evaluation of definite type of production measured in monetary units (1).

$\mathrm{LP}_{\text {product }}=\frac{V_{\text {product }}}{\sum k}$

$\mathrm{LP}_{\text {product }}$ - labor productivity of definite type of production in monetary units;

$\mathrm{V}_{\text {product }}$ - quantity of manufactured product measured in in-house prices;

$\Sigma k$ - total coefficient for definite kind of product (all ratios depending on the scale).

This formula may also be used for calculation in natural units.

Another way of labor productivity estimation is evaluation of manufacturing definite kind of product with a view to one employee (2).

$\mathrm{LP}_{\text {employee }}=\mathrm{LP}_{\text {product }} \frac{\sum k}{\mathrm{~A}_{\text {employee }}}$

$\mathrm{LP}_{\text {employee }}$ - labor productivity, evaluated for definite kind of product with a view to one employee.

$A_{\text {employee }}$ - average number of employees, involved into definite kind of production in investigated period, measured in persons.

\section{RESULTS AND DISCUSSION}

It is very important for investigation to take representative data sample (Paul et al., 2001). Tab. VI aggregates results of $\mathrm{X}^{2}$ test and representativeness of taken dataset sample. To prepare Tab. VI the data is taken from Tab. III. Statistical tests are processed in Excel programme.

Expected number of cases $\left(E_{i}\right)$ could be calculated $=\left(\right.$ Total $\mathrm{O}_{\mathrm{i}} *$ Genesis percent of each

V: Coefficient of labor

\section{Coefficient}

Factor

Constant Additional Constant Additional Constant Additional Constant Additional Constant Additional

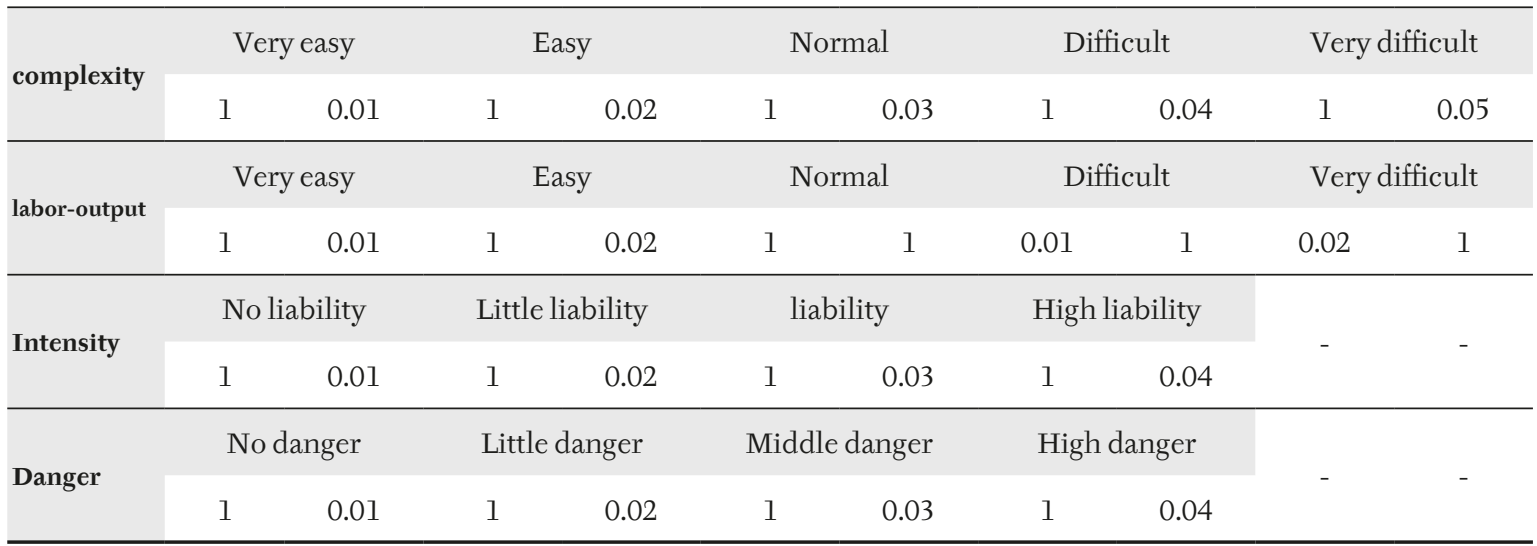

Source: The author's calculation 
coutry)/100. Calculation $\mathrm{E}_{\mathrm{i}}$ for the Czech Republic $=13.491 * 8.01 / 100=1.081$.

The total sum of Chi-Square is 3.774 , but to reject the null hypothesis with 4 degrees of freedom, Chi-Square must be more than 9.488. Thereby, The null hypothesis, meaning that observed number of cases in each country is exactly equal to the expected number of cases in each country, should not be rejected. The dataset sample completely represents the whole population. According Chi-Square test, it is possible to make decision for the whole population, based only dataset sample.

Tab. VII aggregates results of assumptions tests and Kolmogorov-Smirnov test of revenue per person indicator. Shapiro-Wilk normality test identifies abnormal distribution of the dataset; $\mathrm{P}$-value is less than 0.05. It is necessary to use Kolmogorov-Smirnov test for trustable statistical results and Kolmogorov-Smirnov test confirm significance of comparison two sample.

The values reported under W are the Shapiro-Wilk test statistics, $\mathrm{V}$ is more appealing index for departure from normality. The median value $\mathrm{z}$ is 1 for samples from normal population (Royston, 1992).

Results of variance-comparison test and Kolmogorov-Smirnov test confirm the fact, that significance of results and revenue per person in Visegrad group is 2.76 times higher than in Russia. Mean revenue per person are 35.55 thou. EUR for Russia and 98.02 thou. EUR for V4.

Tab. VIII aggregates statistical test results by salary. According to Shapiro-Wilk normality test, The data has normal distribution; P-value is more than 0.05 . It is not needed to use Kolmogorov-Smirnov test. Variance-comparison test shows, that result is significant, P-value is less than 0.05. The mean value of salary per person per year in Visegrad group was 1.9 times higher than in Russia in the period of 2011-2013. Mean revenue per person are 4.82 thou. EUR for Russia and 9.31 thou. EUR for V4.

Thereby, statistical significance result demonstrates that operation revenue per person (labor productivity) and salary is approximately 2 times higher in Visegrad group than in Russia.

This fact is not the basis to make a conclusion that high salary results in high productivity. To estimate correlation between salary and operation revenue per person (labor productivity), statistical method of pairwise correlation is utilized for each group V4 and Russia. The result is presented in Tab. IX. The result is significant; the level of P-value is more than 5 percent. Correlation method is used for the reason of its ability not to identify dependence of variable.

VI: Calculation of $X^{2}$ test on The basis of operation revenue, million \$

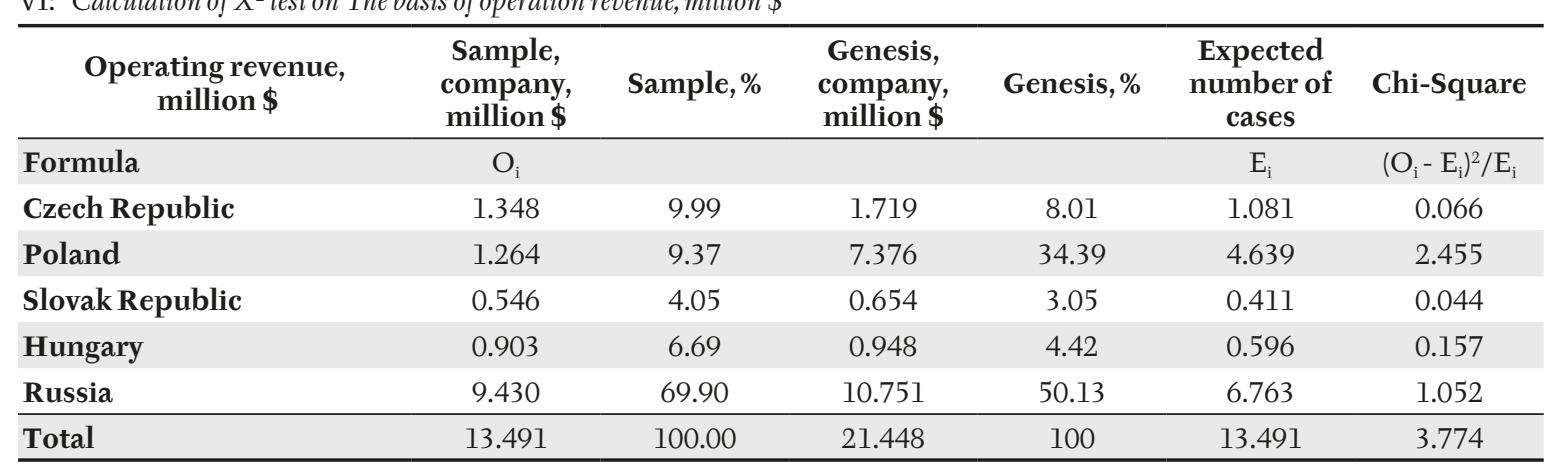

Degrees of freedom $=4$

Ho: ratio = 9.488; Ha: ratio > 9.488; p-value less than 0.05

Source: The author's calculation

VII: Statistical tests of revenue per person (thou. EUR)

\begin{tabular}{|c|c|c|c|c|c|}
\hline S-W test & Obs & $\mathbf{W}$ & $\mathbf{V}$ & $\mathbf{z}$ & p-value \\
\hline V4 & 124 & 0.92904 & 7.020 & 4.374 & 0.00001 \\
\hline V-C test & Mean & Std. Err. & Std. Dev. & \multicolumn{2}{|c|}{ [95\% Conf. Interval] } \\
\hline RU & 35.54962 & 1.240787 & 24.59764 & 33.11019 & 37.989059 \\
\hline ratio $=\mathrm{sd}(\mathrm{RU}) /$ & & \multicolumn{4}{|c|}{ Ho: ratio $=1 ;$ Ha: ratio $!=1 ; p$-value $=0.0000$} \\
\hline K-S test & D & p-value & corrected & \multicolumn{2}{|c|}{ Significance $(\mathrm{a}=0.05)$} \\
\hline RU & 0.5120 & 0.000 & & \multicolumn{2}{|c|}{$\mathrm{RU}<\mathrm{V} 4$} \\
\hline V4 & 0.0000 & 1.000 & & \multicolumn{2}{|c|}{-} \\
\hline
\end{tabular}

Source: Amadeus database, Rosstat, the author's calculation 
VIII: Statistical tests of salary (thou. EUR)

\begin{tabular}{lcccccc}
\hline & S-W test & Obs & W & V & z & p-value \\
\hline RU & 462 & 0.99800 & 0.627 & -1.119 & 0.86846 \\
V4 & 135 & 0.98361 & 1.743 & 1.253 & 0.10511 \\
\hline & V-C test & Mean & Std. Err. & Std. Dev. & \multicolumn{2}{c}{ [95\% Conf. Interval] } \\
\hline RU & 4.824675 & 0.0762656 & 1.639268 & 4.674804 & 4.974547 \\
V4 & 9.318519 & 0.311144 & 3.615167 & 8.70313 & 9.933907 \\
\hline
\end{tabular}

ratio $=s d(R U) / s d(V 4)$

Ho: ratio $=1 ;$ Ha: ratio $!=1 ; p$-value $=0.0000$

Source: Amadeus database, Rosstat, The author's calculation

IX: Spearman's rank correlation between salary and operation revenue per employee

\begin{tabular}{lcc}
\hline & Region & Salary/Operation Revenue per employee \\
\hline RU & 0.1280 \\
V4 & 0.7189 \\
\hline
\end{tabular}

P-value 0.000

Source: Amadeus database, Rosstat, The author's calculation

Sufficiently large correlation is in the EU countries. Correlation between salary and productivity per employee is very small in Russia.

Resuming the result, receiving in Tabs. VI-IX, The dataset are trustable and representative. It was calculated mean for revenue per person and salary per person for V4 and Russia. Statistical tests were confirm representativeness of this calculations. For estimation of dependence per person and salary per person it was used Spearman's rank correlation.

Resuming the investigation, it should be mentioned that the null hypothesis cannot be rejected in case of Russian milk processing industry, though there is no significant correlation between salary and labor productivity. At the same time the null hypothesis should be rejected in case of the EU. Difference of result is quite significant, there is big correlation between salary and labor productivity.

Salary and labor productivity are independent in Russia for some reasons. The employee does not link increased/decreased salary and increased/decreased workforce productivity. Traditionally low salary in agricultural sector might be another reason. Increasing of labor productivity results in increasing of income of a company but employee's salary does not grow. It does not stimulate employee to work efficiently.

Labor is not respected and it might be one more possible reason. Management of a company hires low qualified employees and gives them small salary. Such employees may easily be replaced. There is no sense in improving of labor conditions for low qualified personnel. Such employees aren’t motivated to increase their labor productivity even if their salary is a little bit increased. Working in bad conditions, they do not respect their work and do not trust management of company.

The methodology to control efficiency of labor force and fair salary in Russia is suggested.

$\mathrm{K}=\mathrm{t}_{\mathrm{l}} \times \mathrm{K}_{\mathrm{wc}} \times \mathrm{K}_{\text {lor }} \times \mathrm{K}_{\text {int }} \times \mathrm{K}_{\mathrm{hd}} \times \mathrm{K}_{\text {nex }}$
Each worker gets coefficient depending on work complexity $\left(\mathrm{K}_{\mathrm{wc}}\right)$, labor output ratio $\left(\mathrm{K}_{\text {lor }}\right)$, work intensity $\left(\mathrm{K}_{\mathrm{int}}\right)$, level of danger $\left(\mathrm{K}_{\mathrm{hd}}\right)$ and percent of work execution $\left(\mathrm{K}_{\text {nex }}\right)$.

Constant indicators are $\mathrm{K}_{\mathrm{ws}}, \mathrm{K}_{\text {lor }}, \mathrm{K}_{\mathrm{int}}, \mathrm{K}_{\mathrm{hd}}$. Variable indicator is $\mathrm{K}_{\mathrm{nex}}$.It depends on each worker.

Coefficients depend on type and specificity of work in overall milk industry. Using this method, it is possible to compare productivity, which is not measured in money only, in different companies.

Working efficiency of each person of the company is estimated using coefficient from Tab. V. For example, engine operator Lvov works in danger and, thus, has added coefficient $K_{\text {hd }} 1+0.04$, work intensity $\mathrm{K}_{\mathrm{int}} \mathrm{l}+0.05$ etc. So his total work efficiency is 0.19 more than normal 1 .

Let wage and salaries fund be 356 thou. EUR per year. The number of employees is 50 persons. Hence, coefficient measured in money per month is the following $356000: 12 / 52=593$ EUR. To make fair labor estimation of employee Ivanov, calculation should be the following $1.02 \times 593=604$ EUR per month. This calculation may be used both at definite department and in overall company as well.

Labor productivity $\left(\mathrm{LP}_{\text {product }}\right)$ may be estimated by means of evaluation of definite type of production measured in monetary units, using formula 8.

Let quantity of manufactured product measured in in-house prices fund be 7,120 thou. EUR per year. Labor productivity of company is 136.92 thou. EUR.

$\mathrm{LP}_{\text {product }}=\frac{V_{\text {product }}}{\sum k} \frac{120}{52}=136.92$.

Another way of labor productivity estimation is evaluation of manufacturing of definite kind of product with a view to one employee using formula 9.

$\mathrm{LP}_{\text {employee }}=\mathrm{LP}_{\text {product }} \frac{\sum k}{\mathrm{~A}_{\text {employee }}}=136.92 \frac{52}{50}=142.4$. 
X: Example of coefficients of labor workforce in March, 2014

\begin{tabular}{|c|c|c|c|c|c|c|c|c|}
\hline \multirow[t]{2}{*}{ Name } & \multirow[t]{2}{*}{ Work type } & \multicolumn{6}{|c|}{ Coefficient } & \multirow[t]{2}{*}{ Tota } \\
\hline & & $t_{1}$ & $\mathbf{K}_{\mathrm{ws}}$ & $\mathbf{K}_{\text {lor }}$ & $\mathbf{K}_{\mathrm{int}}$ & $\mathbf{K}_{\text {hd }}$ & $\mathbf{K}_{\text {nex }}$ & \\
\hline Ivanov & Conveyer operator & 1.13 & 1 & 1 & 1 & 1 & 1 & 1.02 \\
\hline Petrov & Manager & 1 & 1.01 & 1.01 & 1.01 & 1.01 & 0.95 & 0.99 \\
\hline Pankov & Product Controller & 1.0 & 1.03 & 1.03 & 1.03 & 1.03 & 1.0 & 1.13 \\
\hline Lvov & Engine operator & 1.0 & 1.05 & 1.05 & 1.05 & 1.04 & 1.04 & 1.19 \\
\hline \multicolumn{9}{|l|}{$\ldots$} \\
\hline Total per montha & & & & & & & 52 & \\
\hline
\end{tabular}

Source: The author's calculation

\section{(11)}

Labor employee was under strong influence of external productivity of one employee is 142.4 thou. EUR per person.

So this method of coefficients helps control both labor productivity of definite employee and overall productivity of company in terms of salary as well.There are investigations devoted to labor productivity and salary. One of them, (Razgune, 2015), analyzes relationship between salary and productivity of an employee in Baltic countries. The authors confirm small relationship between labor productivity and salary. Productivity of factors, like globalization, macroeconomic policies (minimum salary, active labor policies), immigration, size of the shadow economy and others.

It was investigated relationship between compensation salary and labor productivity in Russia in the paper (Galkina, 2011). The several of Russian companies was questioned. If company had compensation salary, than it was large positive relationship between salary and labor efficiency in Russia. The pairwise correlation is 0.8. The Linear regression model also showed big dependence of

both factors. R-square of model was equal 0.70. Result of this paper is not contradict with our research. In our paper it were included companies using compensation salary and don't using it.

\section{CONCLUSION}

The aim of the article is to compare labor productivity and factors, influencing it, in both Visegrad group and Russia in milk processing industry in the period of 2011-2013. Ruble was relatively stable during investigated period that provides good data for comparison without influence of inflation. Number of investigated milk processing companies is 393 in Russia and 124 companies in Visegrad group (The Czech Republic, The Slovak Republic, Poland, Hungary). Representativeness of the sample is proved by Chi-Square method, and statistical comparison of two groups of data is made with Kolmogorov-Smirnov test.

The following results have been obtained:

- 80 percent of all milk processing companies are investigated. These are mainly major companies.

- Salaries and workforce productivity is two times lower in Russia, than in Visegrad group. Average salary per person is 4.82 thou. EUR per year in Russia, and 9.31 thou. EUR in Visegrad group. Productivity is 35.54 thou. EUR per year and 98.01 thou. EUR consequently.

- Correlation between salary and workforce productivity is sufficiently large in Visegrad group, but there is no significant correlation in Russia. Spearman's rank correlation between salary and operation revenue in Visegrad group is 0.71, but in Russia-0.12. Generally speaking, it is sufficiently large dependence between salary and labor productivity in Visegrad group and no dependence in Russia. Increasing of salary does not cause increasing of workforce productivity in Russia. Both personnel motivation system and workforce productivity estimation system is not organized in Russian companies.

- The methodology to control efficiency of labor productivity and salary has been suggested.

- The methodology, based on coefficients given to each employee, allows estimating employee's productivity and comparing it with other employees or comparing companies between each other. An opportunity for next research would be comparison analysis of labor efficiency based on coefficient method.

\section{Acknowledgements}

The article was supported by the institutional support of the University of Economics, Prague, project no. VŠE IP300040. 


\section{REFERENCES}

ALBOROV, R. A., KONTSEVAYA, S. M. and KONTSEVAYA, S. R. 2014. Improvement of Management Accounting of Farm Labor Inputs and Labor Productivity Estimation Improvement in Agriculture. [in Russian: Совершенствование управленческого учета затрат труда и оценки его производительности в сельском хозяйстве]. In: Proceedings of the Russian Scientific Conference. Izhevsk State Agricultural Academy, 6 September. Izhevsk: Izhevsk State Agricultural Academy, pp. 13-20.

BLAUG, M. 1994. Economic thought in retrospect [in Russian: Экономическая мысль в ретроспективе]. Moscow: Delo.

BORSKÁ, J. and KADLECOVÁ, E. 2015. Legal Aspects of Agricultural Land in the Czech Republic. In: Proceedings of the Conference Agrarian perspectives XXIIV. Czech University of Life Sciences, 16-18 September. Prague: Czech University of Life Science, 73-81.

CONOVER, W. 1999. Practical Nonparametric Statistics. 3rd Editon. New York: Wiley.

FEDERAL STATE STATISTICS SERVICE OF THE RUSSIAN FEDERATION. 2016. Differentiation of Workers' Wages by Professional Groups [in Russian: Дифференциация заработной платы работников по профессиональным группам]. [Online]. Available at: http://www.gks.ru/bgd/regl/B12_04/IssWWW.exe/Stg/d06/3-plat.htm [Accessed: 2016, June 24].

DOHMEN, T., LEHMANN, H. and SCHAFFER, M. 2014. Wage Policies of a Russian Firm and the Financial Crisis of 1998: Evidence from Personnel Data - 1997 to 2002. Industrial and Labor Relations Review, 67(2): 504-531.

GALKINA, J. 2011. Development of Methods for Assessing the Effectiveness Compensation ff Wage. Modern Economy: Problems, Trends, Perspectives, 4: 91-97.

KLEIN N. 2012. Real Wage, Labor Productivity, and Employment Trends in South Africa: A Closer Look. IMF Working Paper, WP/12/92. International Monetary Fund.

MEAGER, N. and SPECKESSER S. 2011. Wages, productivity and employment: A review of theory and international data. EEO Thematic Report. European Employment Observatory. Institute for Employment Studies.

MILLEA M. 2002. Disentangling the Wage-Productivity Relationship: Evidence from Select OECD Member Countries. International Advances in Economic Research, (8)4: 314-323.

PASCALAU R. 2007. Productivity Shocks, Unemployment Persistence, and the Adjustment of Real Wages in OECD Countries. MPRA Paper 7222.

PAUL, G. and THIESSEN, V. 2001. Arguing With Numbers Statistics for the Social Sciences. Winnipeg: Fernwood Publishing.

RASTAMKHANOVA, L. N. 2009. The methodology of internal control and its development in a management consulting [in Russian: Методология внутреннего контроля $u$ ее развитие в условиях управленческого консалтинга]. Yoshkar-Ola: String.

RAZGUNE, A. and LAZUTKA, R. 2015. Labor share trends in three Baltic countries: literature review and empirical evidence Ekonomika, 94(1): 98-116.

ROYSTON, P. 1992. Approximating the Shapiro-Wilk W-test for non-normality. Statistics and Computing, 2(3): 117-119.

SHAPIRO C. and STIGLITZ J. 1984. Equilibrium Unemployment as a Worker Discipline Device. American Economic Review, 74(3): 433-444.

URBANCOVÁ, H., ČERMÁKOVÁ, H. and NAVRÁTILOV, M. 2015. Human Resource Diversity Management in Selected Czech Agricultural Companies. Agris on-line Papers in Economics and Informatics, 7(3): 79-87.

FAOSTAT. 2017. Data. [Online]. Available at: http://faostat3.fao.org/home/E [Accessed: 2017, September 26]. 


\section{Appendix}

XI: Comparison Export, Import and Milk production, 2011

\begin{tabular}{lcccccccccc}
\hline $\begin{array}{c}\text { Categories } \\
\text { of milk }\end{array}$ & \multicolumn{2}{c}{ CZ } & \multicolumn{2}{c}{ PL } & \multicolumn{2}{c}{ HU } & \multicolumn{2}{c}{ RU } & & SK \\
\hline & th tons & $\%$ & th tons & $\%$ & th tons & $\%$ & th tons & $\%$ & th tons & $\%$ \\
Production & 2,736 & 100.00 & 12,414 & 100.00 & 1,712 & 100.00 & 31,386 & 100.00 & 928 & 100.00 \\
Imports & 650 & 23.77 & 1,335 & 10.75 & 667 & 38.96 & 2,257 & 7.19 & 617 & 66.42 \\
Export & 1,106 & 40.41 & 3,111 & 25.06 & 523 & 30.56 & 232 & 0.74 & 611 & 65.80 \\
\hline
\end{tabular}

Source: Faostat database, own calculation

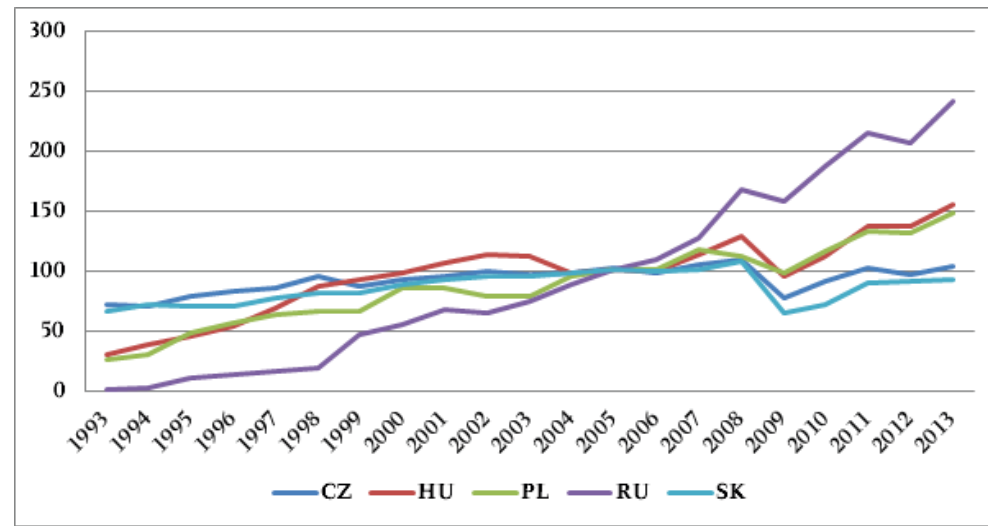

Producer Milk Price Index (1993-2011) in all 5 countries Source: Faostat database

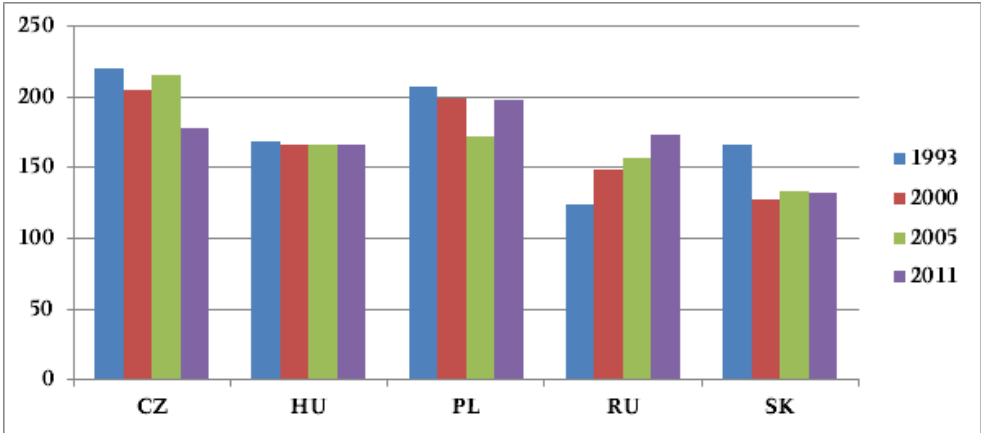

1: Milk consumption kg per capita (1993-2011) in all 5 countries Source: Faostat database

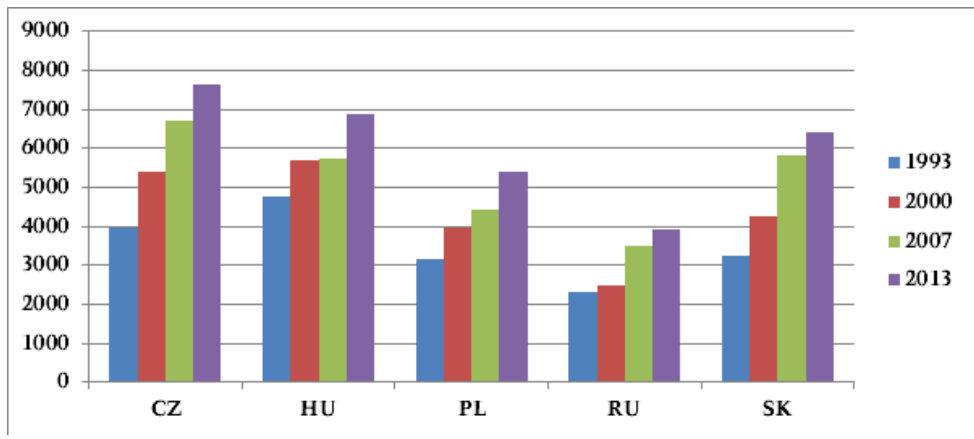

2: Milk yield per cow kg per year (1993-2013) in all 5 countries Source: Faostat database

Contact information

Stanislava Kontsevaya: kontsevaya@mail.ru 